\title{
Serum, milk, saliva and urine progesterone and estradiol profiles in crossbred (Zebu x Holstein Friesian) dairy cattle
}

\author{
Mekonnin $\mathrm{AB}^{1 *}$, Howie $\mathrm{AF}^{1}$, Riley $\mathrm{SC}^{1}$, Gidey $\mathrm{G}^{2}$, Tegegne $\mathrm{DT}^{2}$, Desta $\mathrm{G}^{2}$, Ashebir $\mathrm{G}^{2}$, Gebrekidan $\mathrm{B}^{2}$ and Harlow $\mathrm{CR}^{1}$ \\ ${ }^{1}$ The University of Edinburgh, College of Medicine and Veterinary Medicine, MRC Centre for Reproductive Health, QMRI, 47 Little France Crescent, Edinburgh, \\ EH16 4TJ, UK \\ ${ }^{2}$ Mekelle University, College of Veterinary Medicine, P.O.Box: 231, Tiray, Mekelle, Ethiopia \\ ${ }^{3}$ Tigray Regional State Agriculture Bureau, P.O.Box: 10, Tigray, Mekelle, Ethiopia
}

\begin{abstract}
Effective breeding management is a crucial tool to enhance the reproductive and productive performance of dairy cattle. To achieve this, regular monitoring of their reproductive status is important. The aims of this study were to monitor the reproductive status of crossbred dairy cattle based on progesterone (P4) concentration in serum, whole milk, saliva and urine, and estradiol in serum using quantitative laboratory ELISA tests, and to document hormonal profiles at different reproductive stages. Three hundred and thirty-six (336) crossbred (Holstein Friesian x Zebu) dairy cattle (232 cows and 104 heifers) from 47 dairy farms owned by smallholder or organized commercial dairy farmers were included in the study. Matched blood, milk and saliva samples were collected twice at 11-day intervals at afternoon milking, while urine was collected just once. Serum was separated within $48 \mathrm{hr}$ of blood collection. All samples were stored at $-80^{\circ} \mathrm{C}$ until assayed. In both cows and heifers, P4 was higher during pregnancy than in other reproductive conditions. Estradiol was higher during estrus than at other reproductive stages. Estradiol levels were significantly higher $(\mathrm{p}<0.05)$ in estrus cows compared with heifers. The mean level of $\mathrm{P} 4$ in serum strongly correlated with the value in milk $(\mathrm{r}=0.6368, \mathrm{P}<0.0001)$ however there was no correlation in $\mathrm{P} 4$ concentration between serum and saliva or between $\mathrm{P} 4$ in serum and in urine. Hence, determination of $\mathrm{P} 4$ in serum and milk using an ELISA test is a reliable and precise method to monitor reproductive status in crossbred dairy cattle.
\end{abstract}

\section{Introduction}

Effective breeding management is a crucial tool to enhance the reproductive and productive performance of dairy cattle. Failure to detect and correctly interpret signs of estrus can contribute to significant loss in the dairy industry [1,2]. Although, visual observation of animals for signs of estrus is a common method of estrus detection across the globe, in developed countries objective tests are used to confirm estrus [3], including measuring serum/plasma or milk progesterone (P4) levels, and to successfully breed cattle.

Progesterone plays an essential role in various reproductive functions, including regulating the length of the estrous cycle, maintaining pregnancy $[4,5]$ and regulating embryonic growth and development [6,7]. P4 is high during the luteal phase and in pregnancy, however the levels decline if the animal fails to conceive $[8,9]$. Monitoring P4 in plasma/serum [10,11] or milk [11-13] using an Enzyme Linked Immunosorbent Assay (ELISA) or Radioimmunoassay (RIA) has been used to assess the reproductive status of cattle and ensure successful breeding, or inform decisions to cull non-productive cows/heifers. Additionally, it has been used to detect pathology of the reproductive system such as cystic ovaries [14].

Determination of P4 in saliva using ELISA has also been used to determine the reproductive status in farm animals [15-17] as well as in women [18]. However, determination of P4 concentration alone is not sufficient to predict ovulation because there is a large variation in the timing of P4 decrease relative to ovulation [19]. Ovarian estradiol plays an important role in establishing the timing of uterine receptivity to the developing embryo [20] and embryo survival [21]. In the bovine, estrus is initiated after a rise in circulating estradiol level [22]. Identifying the estradiol peak can precisely indicate pre-ovulation [13], which may assist prediction of insemination timing yielding high conception rates. Circulating concentrations of estradiol during the preovulatory period can influence the establishment and maintenance of pregnancy by altering the uterine environment $[21,23]$. Additionally, estradiol is proposed to induce FSH/ LH receptor expression in granulosa cells [24] and increase the stimulatory action of FSH on aromatase activity [25].

In Ethiopia, pregnancy diagnosis in cattle is only carried out using per-rectal palpation by AI technicians or veterinarians [11]. Recently, we showed that qualitative on-farm milk/serum P4 ELISA tests effectively diagnosed pregnancy as early as 18-days post service and confirmed cyclicity in cattle [26]. However, the on-farm qualitative testing does not quantify P4 levels in cattle, and is designed only to determine the relative $\mathrm{P} 4$ concentration (high or low) [27]. As dry cows and heifers are not lactating, it is not feasible to use milk to determine P4 levels, so urine or saliva samples are attractive alternatives for monitoring reproductive status [16].

The metabolism of P4 is rapid and occurs mainly in the liver [28-30]. The P4 metabolites are released from the liver into the

${ }^{\star}$ Correspondence to: Mekonnin AB, The University of Edinburgh, College of Medicine and Veterinary Medicine, MRC Centre for Reproductive Health, QMRI, 47 Little France Crescent, Edinburgh, EH16 4TJ, UK; E-mail: alemselambnh@yahoo.com

Key words: Cattle, estradiol, ELISA, P4, reproductive status

Received: September 07, 2017; Accepted: September 26, 2017; Published: September 29, 2017 
blood circulation, and excreted by the kidneys into the urine $[28,30]$. Pregnanediol glucuronide is a common urinary metabolite of P4 [3135]. Volkery et al. [36] reported that plasma concentration of $\mathrm{P} 4$ and estrone sulphate correlated with pregnanediol-3-glucuronide and estrone sulphate levels in matched urine in female alpacas. Similarly, estrone conjugates and pregnanediol glucuronide in urine were measured using RIA and/or EIA, and their value paralleled the profile of the parent steroid in serum/plasma in women [32,37].

Changes in total P4 circulation in blood (protein - bound plus free, non-protein bound fractions) have been widely used for accurate monitoring of reproductive status in cows $[15,16,38-40]$. Over $80 \%$ of circulating P4 is bound to plasma proteins $[41,42]$ and only the free fraction is biologically active $[43,44]$. Sex steroids in saliva can be used as an index of their unbound plasma concentration $[43,45,46]$. Hence, the quantitative correlation between the two fractions could be used to determine $\mathrm{P} 4$ concentration in matched blood and saliva samples $[15,47,48]$.

Saliva and urine have the advantage of being non-invasive and relatively stress-free methods and can easily be collected by farmers [48-50]. However, P4 profiles at different reproductive stages of crossbred cattle in Tigray region and other parts of Ethiopia are not well established. The aims of this study were to monitor the reproductive status of crossbred dairy cattle based on P4 concentrations in serum, whole milk, saliva and urine, and estradiol in serum using quantitative laboratory ELISA tests, and to document $\mathrm{P} 4$ and estradiol profiles at different reproductive stages.

\section{Materials and methods}

\section{Study animals}

The study was approved by The Government of National State of Tigray Bureau of Agriculture and Rural Development, Tigray, Ethiopia, and by The University of Edinburgh Committee on Ethics of Animal Research. Samples were imported to the UK for laboratory analysis by fulfilling all the necessary requirements stated on the Import Authorization of Animal Products/Biological samples for Study or Analysis [TARP(S)2014/23], according to the Trade in Animals and Related Products (Scotland) Regulations 2012, issued by the Agriculture, Food and Rural Communities Directorate of the Scottish Government. A total of 336 crossbred (HF x Zebu) dairy cattle (232 cows and 104 heifers) from 47 dairy farms owned by smallholder/ organized commercial dairy farmers were included in the study. Their husbandry practice was as described by Hailu et al. [51].

\section{Selection of study animals}

Overtly healthy animals, having a mean BCS of 3.1, range 2.5-4 (using a scale of 1-5) were included in the study [52]. According to breeding history (farmer's observation), animals that had never come into estrus 60 to 90 days postpartum (anestrus), repeaters, pregnant animals ( $>18$ days post $\mathrm{AI} / \mathrm{mating}$ ) and those that were reported inheat at the time of sample collection were included. Breeding history of each animal in the experimental group was taken. Reproductive status was confirmed on the farm by qualitative on-farm P4 assays and animals were grouped accordingly as anestrus, in-heat, diestrus and pregnant $\left(1^{\text {st }}\right.$ trimester, $2^{\text {nd }}$ trimester and $3^{\text {rd }}$ trimester $)$.

\section{Sample collection}

Blood collection and serum separation: Blood was collected in 10 $\mathrm{ml}$ plain vacutainer tubes (BD Vacutainer ${ }^{\oplus}, \mathrm{BD}$, Plymouth, UK) from the jugular vein of dry cows and heifers twice at eleven-day intervals.
Blood was allowed to clot at room temperature for 24-48 hr after collection and serum was separated. Serum was stored in $5 \mathrm{ml}$ capacity sterile plastic transport tubes (Alpha Laboratories, Hampshire, UK) and stored at $-80^{\circ} \mathrm{C}$ until assayed.

Milk collection: Milk (10-20ml per animal) was collected into plastic centrifuge tubes (Alpha Laboratories) twice at eleven-day intervals from lactating dairy cows. Samples (foremilk) were taken manually from all four quarters after discarding the first four milk drops. Milk was collected only from cows with a clinically healthy udder and teats. Samples were frozen at $-80^{\circ} \mathrm{C}$ until assayed.

Saliva collection: Saliva ( $5 \mathrm{ml}$ from each animal) was collected from dairy cows and heifers twice at 11-day intervals using a $7 \mathrm{ml}$ capacity plastic transfer pipette directly from the buccal commissures by aspiration. In cases when insufficient saliva was collected, animals were provided with some green feed or hay/straw to stimulate salivation, and in some cases saliva dropping out of the mouth was collected directly to the sterile, plastic transport tubes (Alpha Laboratories). Samples were transported from the farms to the laboratory in a cooling box with ice and samples were centrifuged at $4000 \mathrm{~g}$ for $10 \mathrm{~min}$ at $20^{\circ} \mathrm{C}$ to remove any contaminating food particles. In some cases, samples were frozen and centrifuged, multiple times until food particles were completely removed. Samples were stored at $-80^{\circ} \mathrm{C}$ until assayed. Collection procedures were based on previous reports $[15,16]$.

Urine collection: Urine $(5 \mathrm{ml} / \mathrm{cow})$ was collected when cows urinated normally or following stimulation through massaging the ventral commissure of the vulva. Samples were frozen at $-80^{\circ} \mathrm{C}$ until assayed.

\section{Experimental design}

Steroid hormone extraction: Whole milk, saliva and urine were used without steroid extraction (intact) for P4 measurement. Steroids were extracted from serum for both $\mathrm{P} 4$ and estradiol measurements. Extraction procedures were as follows: $120 \mu \mathrm{l}$ (for P4 measurement) or $250 \mu \mathrm{l}$ (for estradiol) of serum, standards or controls were added into 16 $\mathrm{x} 100 \mathrm{~mm}$ glass tubes. $2 \mathrm{ml}$ (for P4) or $3 \mathrm{ml}$ (for estradiol) diethyl ether (Sigma-Aldrich, St. Louis, MO, USA) was then added to each glass tube and steroids were extracted on a muli-vortexer (IKA ${ }^{\circ}$ Vibrax VXR basic, Staufen, Germany) for $5 \mathrm{~min}$. Extracted samples were frozen in an ethanol (VWR International, Fontenay-sous Bois, France) plus dry ice bath, and the ether layer decanted. Extracted samples were dried overnight in a fume cupboard, or dried down rapidly under a stream of nitrogen in a hot block (Dri-Block ${ }^{\star}$ DB-3, Techne Ltd, Cambridge, UK) at $40^{\circ} \mathrm{C}$ for a maximum of $1 \mathrm{hr}$. Extracted samples were reconstituted by vortexing with charcoal-stripped serum (volume equal to original volume of sample) and assayed immediately or stored short term at $4^{\circ} \mathrm{C}$ until assayed.

P4 determination in serum, whole milk, saliva and urine: Quantitative in-house laboratory ELISA that was developed by Dr. Forbes Howie (MRC Centre for Reproductive Health, The University of Edinburgh, UK) was adapted to quantify the level of P4 in serum, whole milk, saliva and urine. All samples, standards and controls were first thawed at $4^{\circ} \mathrm{C}$, and then warmed to room temperature. Whole milk and saliva samples were further warmed in a tube warmer (Dri-Block, Bibbi Scientific Ltd., Stone, Staffordshire, UK) at $40-50^{\circ} \mathrm{C}$ for $40 \mathrm{~min}$ to homogenize the milk and to break down the mucin present in saliva.

ELISA was performed by coating 96-well plates (Greiner Bio-One $\mathrm{GmbH}$, Frickenhausen, Germany) with $100 \mu$ l of primary antibody (rabbit anti-P4, AbD Serotec, Kidlington, UK) per well at a dilution 
of 1:1000 in coating buffer (100mM Na Bicarbonate, $\mathrm{pH} 9.6)$, covered with parafilm incubated overnight at $4^{\circ} \mathrm{C}$ and then washed 3 times with wash solution (BioWhittaker ${ }^{\oplus}$ PBS, Lonza, Verviers, Belgium) + 0.05\% Tween 20 (Tween ${ }^{\circledR}$ 20, SigmaAldrich, Inc., St. Louis, MO, USA). Standards, samples and controls $(50 \mu$ l per well) were added to each well, followed by $50 \mu$ of secondary antibody, Progesterone 3 - HRP conjugate (Meridian Life Sciences, Inc., Memphis, USA) 1:500 in assay buffer. Plates were incubated at room temperature for $2 \mathrm{hr}$ on a microtitre plate shaker (IKA ${ }^{\star}$, Schuttler MTS4, IKA Labortechnik, Staufen, Germany), then washed 5 times and $100 \mu$ of substrate solution (3,3,5,5-Tetramethylbenzidine/ TMB; EMD Millipore Corporation, Temecula, CA, USA) was added to each well. Plates were incubated at room temperature without shaking for serum and milk samples, or at $30^{\circ} \mathrm{C}$ on an Orbital Incubator (Stuart ${ }^{\circ}$, Stone, Staffordshire, UK), all in the dark. After $20 \mathrm{~min}$, once a blue colour was developed, the reaction was stopped by adding $100 \mu \mathrm{l}$ of $2 \mathrm{NH} 2 \mathrm{SO} 4$ solution (Sigma-Aldrich Company Ltd., Dorset, UK). Finally, plates were read on a plate reader at $450 \mathrm{~nm}$.

Standard curves were prepared with a total of 8 different concentrations $(40.0,20.0,10.0,5.0,2.5,1.25,0.613,0.0 \mathrm{ng} / \mathrm{ml})$ to measure $\mathrm{P} 4$ concentration in serum (Figure 1A) and whole milk, or 8.0, $4.0,2.0,1.0,0.5,0.25,0.125,0.0 \mathrm{ng} / \mathrm{ml}$, to measure P4 in saliva (Figure 1B). Samples, standards and controls were included in duplicate. Interand intra-assay CV were calculated from two controls of low and high P4 in duplicate in each of eight assays. The inter-assay CV for low and high pools respectively were 17.4 and $13.1 \%$ for serum, 2.6 and $7.1 \%$ for milk, and 8.6 and $12.7 \%$ for saliva P4, and the intra-assay CV were 8.9 and $11.6 \%$ for serum, 2.0 and $11.2 \%$ for milk, and 11.7 and $4.7 \%$ for saliva P4. Cross-reaction with other steroids was: estrone: $0.17 \%$, estradiol: $0.28 \%$, estriol: $0.18 \%$, DHEA: $0.02 \%$, testosterone: $0.36 \%$, DHT: $0.15 \%, 17$-hydroxyprogesterone: $2.9 \%$, androstenedione: $0.14 \%$, 11-deoxycortisol: $0.46 \%$, corticosterone: $0.18 \%$, cortisone: $0.04 \%$ and cortisol: $0.04 \%$.

Urine P4 ELISA: The same ELISA protocol as used for saliva was used to determine P4 in urine, without extraction. The P4 level in each urine sample was divided by the creatinine level in the same sample to adjust for dilution effects. Creatinine was determined using the creatininase/creatinase specific enzymatic method described by Bömer et al. [53] utilizing a commercial kit (Alpha Laboratories Ltd.) adapted for use on a Cobas Fara centrifugal analyzer (Roche Diagnostics Ltd.,
Welwyn Garden City, UK). Within run precision was $\mathrm{CV}<3 \%$ while intra-batch precision was $\mathrm{CV}<5 \%$.

Estradiol measurement in serum: Estradiol was measured using Estradiol Sensitive ELISA kit according to the manufacturer's instructions (Demeditec Diagnostics $\mathrm{GmbH}$, Kiel, Germany). Steroids were extracted prior to assaying. Wells were precoated with a polyclonal anti-estradiol antibody; $100 \mu \mathrm{l}$ of each standard $(0,3,10,50,200 \mathrm{pg} / \mathrm{ml}$ of estradiol), control and samples were added into appropriate wells. Then, $200 \mu \mathrm{l}$ enzyme conjugate was added into each well, thoroughly mixed for 10 seconds on a plate shaker and plates were incubated for $4 \mathrm{hr}$ at room temperature. Plates were washed 3 times with $400 \mu \mathrm{l}$ per well of wash solution and $200 \mu \mathrm{l}$ of TMB was added to each well, and then plates incubated for $30 \mathrm{~min}$ at room temperature. The reaction was stopped by adding $100 \mu$ stop solution. Finally, plates were read on plate reader at $450 \mathrm{~nm}$. Inter- and intra-assay $\mathrm{CV}$ were determined as for P4, and were $15.2 \& 18.1 \%$ and $13.6 \& 13.5 \%$ for high and low pools of controls, respectively. Cross-reactivity of antiestradiol antibody was reported as $0.2 \%$ for estrone, $0.05 \%$ for estriol and $<0.001 \%$ for a range of other steroids (Demeditec Diagnostics $\mathrm{GmbH}$ ).

\section{Statistical analysis}

Data was analysed using GraphPad Prism 6. Data was checked for normal distribution using D'Agostino-Pearson Test, and analysed using one-way ANOVA. Post hoc Dunn's multiple comparisons test was used to compare $\mathrm{P} 4$ level between pregnant cows and pregnant heifers, between $1^{\text {st }}, 2^{\text {nd }}$ and $3^{\text {rd }}$ trimester pregnancies within cows and heifers, between in heat and diestrus cows and heifers and between diestrus and pregnant animals.

\section{Result \\ P4 profiles}

Laboratory serum P4 ELISA results were considered as gold standard to classify and confirm reproductive status. The P4 level in milk, saliva and urine was measured once cattle were classified into their respective reproductive status following serum $\mathrm{P} 4$ determination. Three different assays were developed for three different sample types, serum, milk and saliva/urine. Extraction of steroids was performed for serum, to avoid any solvent recovery interference; standards and controls went through the extraction processes at the same time as the
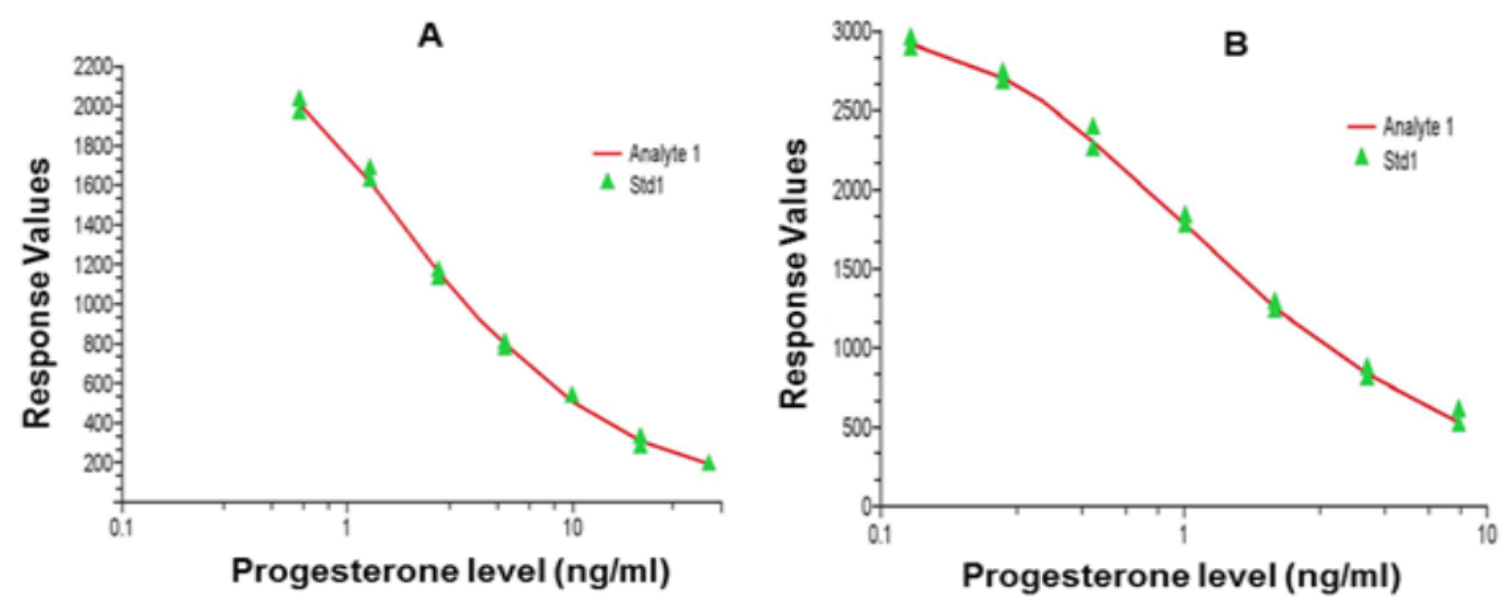

Figure 1. Representative examples of standard curves for serum (A) and saliva (B) P4 (ng/ml) determination using the laboratory ELISA test. 
unknown samples. Extraction was deemed unnecessary for saliva/urine assay. Extraction of steroids for milk proved unsuccessful; therefore, P4 measurements had to be done without extraction.

\section{Serum P4}

The mean levels of $\mathrm{P} 4$ in serum strongly correlated with the level in milk ( $\mathrm{r}=0.6368, \mathrm{P}<0.0001)$ (Figure $2 \mathrm{~A}$ ), however there was no significant correlation between serum and saliva $\mathrm{P} 4$ or between serum and urine P4 levels (Figure 2 B, C and D). Serum P4 measurement in crossbred dairy cattle in different reproductive states is indicated in Figures 3, 4 and 5. Cattle with P4 levels of $\geq 1 \mathrm{ng} / \mathrm{ml}$ in either of the tests (measured twice at 11-day intervals) were considered to have functional ovaries; hence, animals were regarded as normally cycling. In contrast, cattle with low $\mathrm{P} 4$ level $(<1 \mathrm{ng} / \mathrm{ml})$ in both tests had non-functional ovaries (no CL or follicle detected per rectum) and were considered as anestrus. Cattle that were observed in-heat and had a low P4 level (P4 $<\mathrm{nng} / \mathrm{ml}$ ) were considered in-heat or follicular phase. All other animals that had a history of insemination and serum $\mathrm{P} 4 \geq 1 \mathrm{ng} / \mathrm{ml}$ at both tests, together with per-rectal palpation findings, were considered pregnant. The P4 levels (Mean \pm SEM) of three cows that had ovarian follicular cysts was measured in matched serum and milk, and were 0.37 and 0.13 $\mathrm{ng} / \mathrm{ml}$ respectively.

The mean serum $\mathrm{P} 4$ in cows and heifers either in-heat or anestrus was below $1 \mathrm{ng} / \mathrm{ml}$ (Figure 3 ). There was similar serum P4 levels in cows and heifers that were either anestrus, in-heat or in their $3^{\text {rd }}$ trimester pregnancy. Significantly higher $(\mathrm{p}<0.05) \mathrm{P} 4$ was recorded in heifers than in cows in diestrus and in the $1^{\text {st }}$ trimester; whereas significantly higher P4 was detected in cows compared with heifers in $2^{\text {nd }}$ trimester. While most normally cycling cattle had $<1 \mathrm{ng} / \mathrm{ml}$ of $\mathrm{P} 4$ in one of the tests (first or second test), 22 cattle (10 cows and 12 heifers) had P4 levels $\geq 1 \mathrm{ng} / \mathrm{ml}$ in both the tests. In contrast, two pregnant cows $\left(1^{\text {st }}\right.$ and ${ }^{2 n d}$ trimester, each) had low $(<1 \mathrm{ng} / \mathrm{ml})$ serum $\mathrm{P} 4$ concentration, whereas none of the pregnant heifers had $<1$ ng serum $\mathrm{P} 4$. The overall mean $\mathrm{P} 4$ level in pregnant cows was significantly higher $(\mathrm{p}<0.05)$ than in pregnant heifers. Cows that were in $1^{\text {st }}$ trimester of pregnancy had significantly lower $(\mathrm{p}<0.05)$ serum $\mathrm{P} 4$ levels than heifers at the same stage of pregnancy. In contrast, significantly higher $(p<0.05)$ serum $\mathrm{P} 4$ was detected in cows compared with heifers during $2^{\text {nd }}$ trimester. $\mathrm{P} 4$ concentration in serum was similar between pregnant and diestrus heifers (Figure 4), however pregnant heifers had significantly higher $(\mathrm{p}<0.05) \mathrm{P} 4$ in saliva than had diestrus heifers. In contrast, there was significantly higher $(\mathrm{p}<0.05)$ serum and milk $\mathrm{P} 4$ concentration in pregnant than diestrus cows (Figure 3).

\section{Milk P4}

Milk P4 concentration was determined in 200 lactating cows. Similar to serum, the level of P4 in milk was low in cows that were anestrus and in-heat, 0.16 and $0.14 \mathrm{ng} / \mathrm{ml}$, respectively (Figure 3). The P4 levels in diestrus cows and heifers were similar (Figure 3 ). The overall mean $\mathrm{P} 4$ in milk was significantly higher $(\mathrm{p}<0.05)$ in pregnant cows compared to those in diestrus (Figure 3 ). Cows that were in their
A
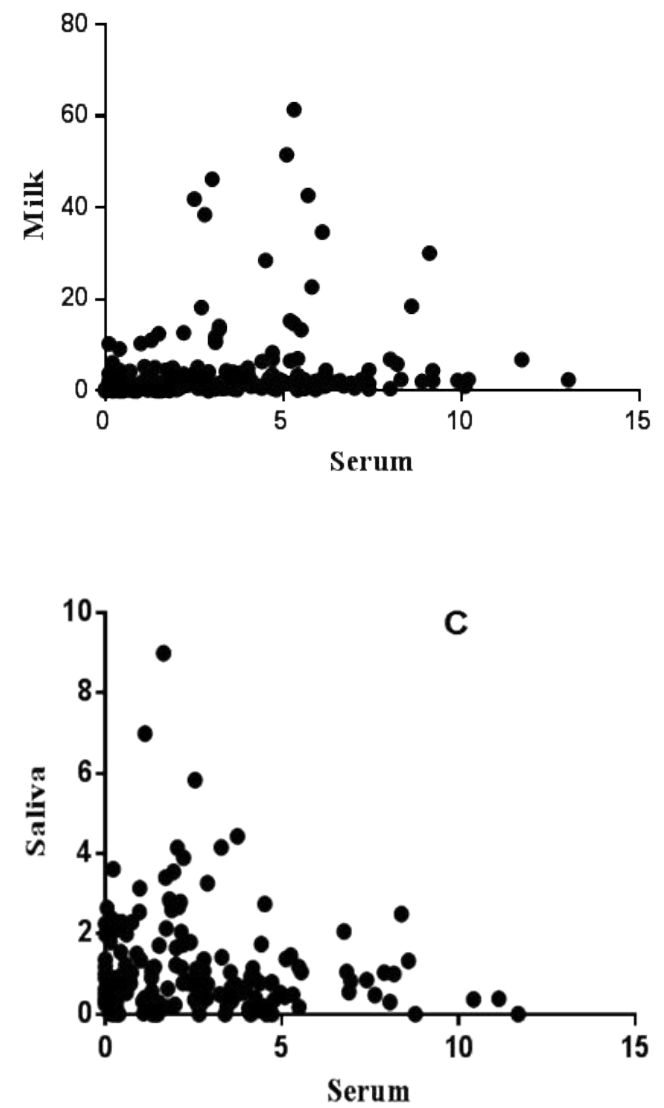

B
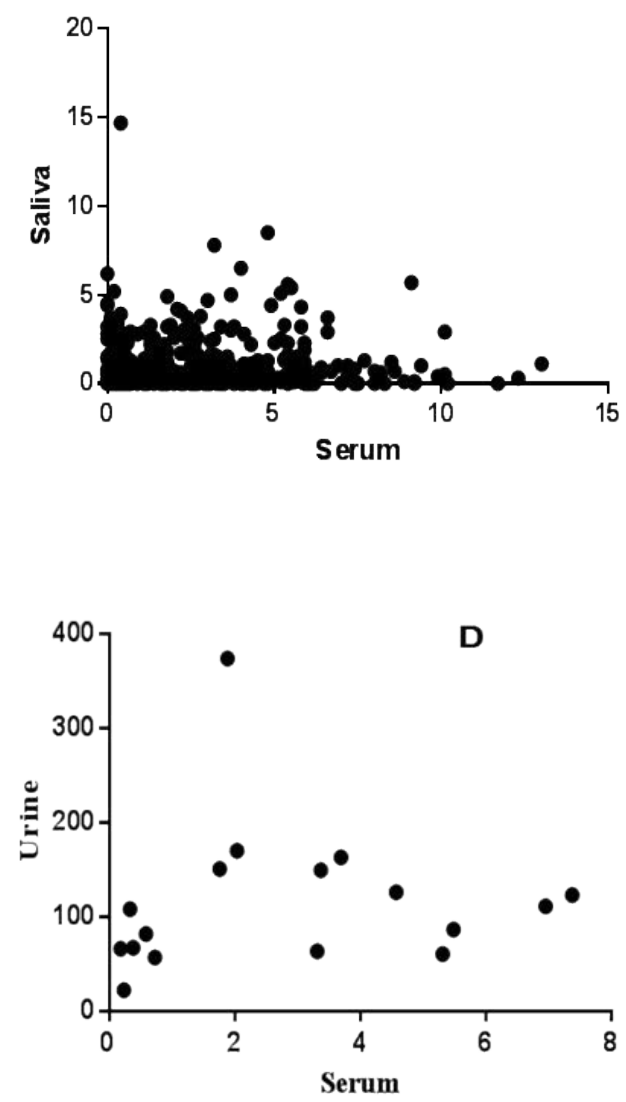

Figure 2. Correlation of serum vs milk (A) and serum vs saliva (B) $\mathrm{P} 4$ concentrations in cows, serum vs saliva $\mathrm{P} 4$ in heifers $(\mathrm{C})$ and serum vs urine $\mathrm{P} 4$ in cows $(\mathrm{D})$. A: $(\mathrm{r}=0.6368$, $\mathrm{P}<0.0001$, $\mathrm{n}=232)$; $\mathrm{B}:(\mathrm{r}=0.02439, \mathrm{P}=0.6329, \mathrm{n}=232)$; $:(\mathrm{r}=-0.02213, \mathrm{P}=0.7791, \mathrm{n}=104)$; $\mathrm{D}:(\mathrm{r}=0.3284, \mathrm{P}=0.1979, \mathrm{n}=30)$. $\mathrm{P}<0.05$ is significant; $\mathrm{r}$ : correlation coefficient. 


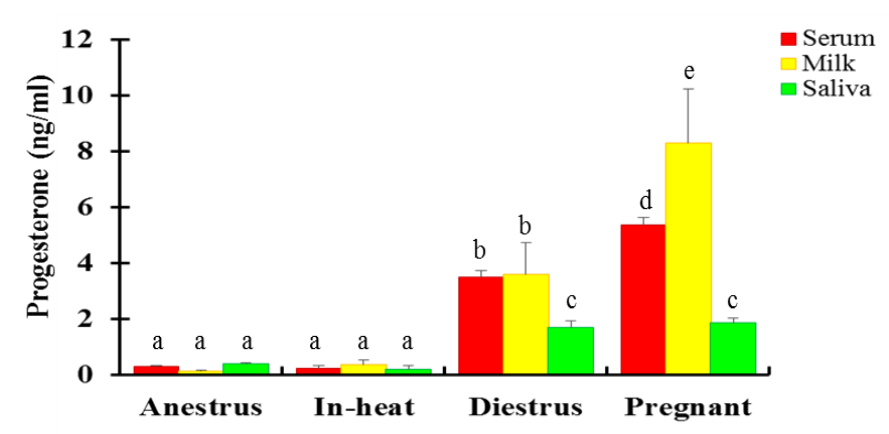

Figure 3. P4 concentration in serum (red), milk (yellow) and saliva (green) at different reproductive stages in crossbred dairy cows (Mean \pm SEM, ng/ml). N=232: 45 anestrus; 7 inheat; 66 diestrus; 114 pregnant). Of 7 cows in-heat, two were included following induction of estrus using a combination of CIDR-PGF2 $\alpha-\mathrm{eCG}$ (Chapter 6). Bars with different letters are significantly different, $\mathrm{p}<0.05$; two-way ANOVA.

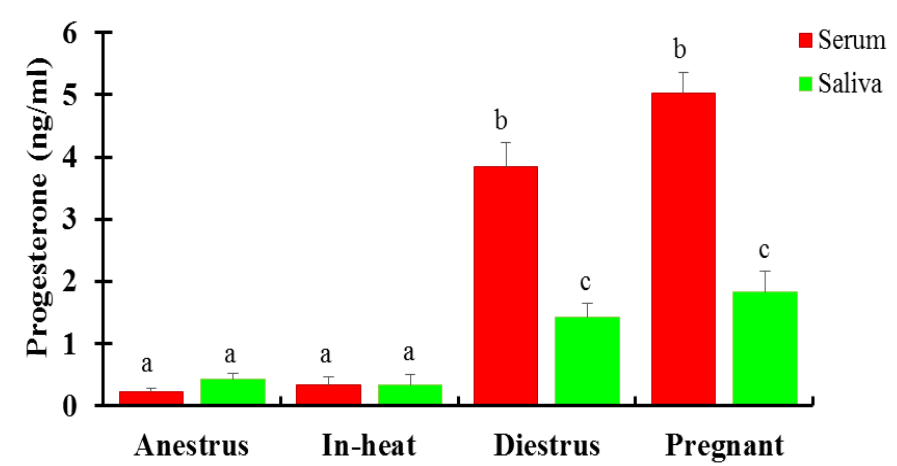

Figure 4. $\mathrm{P} 4$ concentration (Mean $\pm \mathrm{SEM}, \mathrm{ng} / \mathrm{ml}$ ) in serum and saliva in crossbred dairy heifers in different reproductive states. $\mathrm{N}=104$ : 18 anestrus; 5 in-heat; 38 diestrus; 43 pregnant); Bars with different letters are significantly different, $\mathrm{p}<0.05$; two-way ANOVA.

$3^{\text {rd }}$ trimester of pregnancy had significantly higher $(\mathrm{p}<0.05)$ milk P4 than cows in other stages of pregnancy. Milk P4 in cows at $2^{\text {nd }}$ trimester pregnancy was lower than those at $1^{\text {st }}$ and $3^{\text {rd }}$ trimester (Figure 5). Eight pregnant crossbred cows (one in $1^{\text {st }}$ trimester, six in $2^{\text {nd }}$ trimester and one in $3^{\text {rd }}$ trimester) had milk P4 levels $<1 \mathrm{ng} / \mathrm{ml}$.

\section{Saliva P4}

The P4 level in saliva in anestrous cows and heifers was low, and similar to cattle in-heat. It was also similar to the levels in serum and milk (Figure 3 \& 4). Similarly, cows in-heat had similar saliva P4 levels to heifers in-heat. Diestrus cows and heifers had significantly higher ( $\mathrm{p}$ $<0.05$ ) saliva P4 levels than those in anestrus or in-heat. Conversely, diestrus cows/heifers had significantly lower $(\mathrm{p}<0.05)$ mean P4 concentrations in saliva than pregnant cows. A significantly lower $(p<0.05)$ P4 level was detected in saliva than in serum and milk in diestrus and pregnant cattle. Pregnant cows had a similar overall mean P4 to pregnant heifers. Pregnant cattle had low saliva P4 level (0.13ng/ $\mathrm{ml})$ in their second trimester of pregnancy. Significantly higher $(\mathrm{p}<$ $0.05)$ saliva $\mathrm{P} 4$ was detected in cows in $1^{\text {st }}$ trimester than the $2^{\text {nd }}$ and $3^{\text {rd }}$ trimester (Figure 5), with similar P4 between $2^{\text {nd }}$ and $3^{\text {rd }}$ trimesters. The P4 levels in saliva were significantly lower $(\mathrm{p}<0.05)$ than in serum in both cows and heifers and in milk in cows at all stages of pregnancy (Figure 5). In heifers, $\mathrm{P} 4$ was significantly higher $(\mathrm{p}<0.05)$ in $1^{\text {st }}$ and $3^{\text {rd }}$ trimester compared with $2^{\text {nd }}$ trimester, with similar $\mathrm{P} 4$ levels between $1^{\text {st }}$ and $3^{\text {rd }}$ trimesters (Figure 5).

\section{Urine P4}

The mean urine concentration of $\mathrm{P} 4$ in pregnant cows was 119.24 $\mathrm{ng} / \mathrm{mg}$ of creatinine. A significantly higher $(\mathrm{p}<0.05)$ P4 level was detected in pregnant cows than in cows that were anestrus and in estrus (Figure 6).

\section{Serum estradiol profile}

Serum estradiol concentration was estimated using a laboratory ELISA test (Figure 7A \& B). Anestrus and diestrus cattle had significantly lower $(\mathrm{p}<0.05)$ estradiol concentration compared with cattle in other reproductive stages, and the level was similar between cows and heifers. A significantly higher $(\mathrm{p}<0.05)$ estradiol concentration was measured in cows which were in estrus than cows in other reproductive states. Pregnant heifers in term trimester had significantly higher $(\mathrm{p}<0.05)$ estradiol levels than heifers in-heat and in other reproductive states. A significantly higher $(\mathrm{p}<0.05)$ difference was found in serum concentration of estradiol in cows than heifers that were in estrus. In contrast, a significantly higher $(\mathrm{p}<0.05)$ estradiol level was detected in pregnant heifers than in cows in their first trimester. In both cows and heifers, higher estradiol concentrations were recorded during term pregnancy in contrast to other stages of pregnancy (Figure 7B).

\section{Discussion}

\section{P4 detection in non-pregnant cycling and anestrous cattle}

In the present study, cattle in estrus had low concentrations of $\mathrm{P} 4(<$ $1 \mathrm{ng} / \mathrm{ml})$, which is in line to previous reports in serum [54-57], plasma in Zebu cows [58] and milk [58-60]. In contrast, Rajamahendran et al. [61] reported that 32 (4.8\%) cows that were submitted for breeding had milk P4 $\geq 1 \mathrm{ng} / \mathrm{ml}$, that was in line with other reports [62-65]. Saliva P4 concentration in cattle in estrus in this study was higher than in previous reports in Friesian/Jersey cows [16]. It has been demonstrated that P4 levels during the follicular phase fluctuates from 0.025 to $0.08 \mathrm{ng} / \mathrm{ml}$ [15]. Although P4 levels are low when cows/heifers are in estrus, a low concentration of $\mathrm{P} 4$ does not necessary mean the animal is in estrus, as anestrous cattle with small ovaries without palpable follicles or $\mathrm{CL}$, also have low levels of P4. However, it has been proposed that high P4 accurately confirms that the animal is not in estrus, even when animals exhibit behavioral symptoms of estrus [27]. This suggests inaccurate estrus detection [66]. The use of on-farm or laboratory P4 assays had played a significant role in identifying cycling (in-heat and those in the luteal phase) cattle. This increases the chance of breeding cattle in-heat and properly detecting when animals in the luteal phase subsequently come into estrus.

The present study has determined the $\mathrm{P} 4$ concentration in urine. Urinary creatinine concentration was used as a reference to determine P4 levels $[67,68]$, based on previous reports suggesting urinary creatinine excretion is constant in individual animals $[69,70]$. However, a recent report has shown that P4 metabolites (such as pregnanediol glucuronide) concentration can be measured for monitoring reproductive status of dairy cows without the need for creatinine adjustment [49]. Yang et al. [49] has shown that the correlation between the urinary pregnanediol glucuronide and serum P4 was higher without adjustment than when adjusted by urinary creatinine concentration, which is in line with our finding whereby the level of P4 in serum and in urine was not correlated. Furthermore, studies on ovarian function in women using urinary steroid assays have shown that the correlation between serum steroid and their metabolite levels in urine was improved when not adjusted for creatinine levels [32]. The P4 profile in urine of cows that were in heat, in the present study, was similar to a previous report in North American Bison cows [71]. The concentration of P4 (steroid) metabolite varies widely among different animal species [49]. 

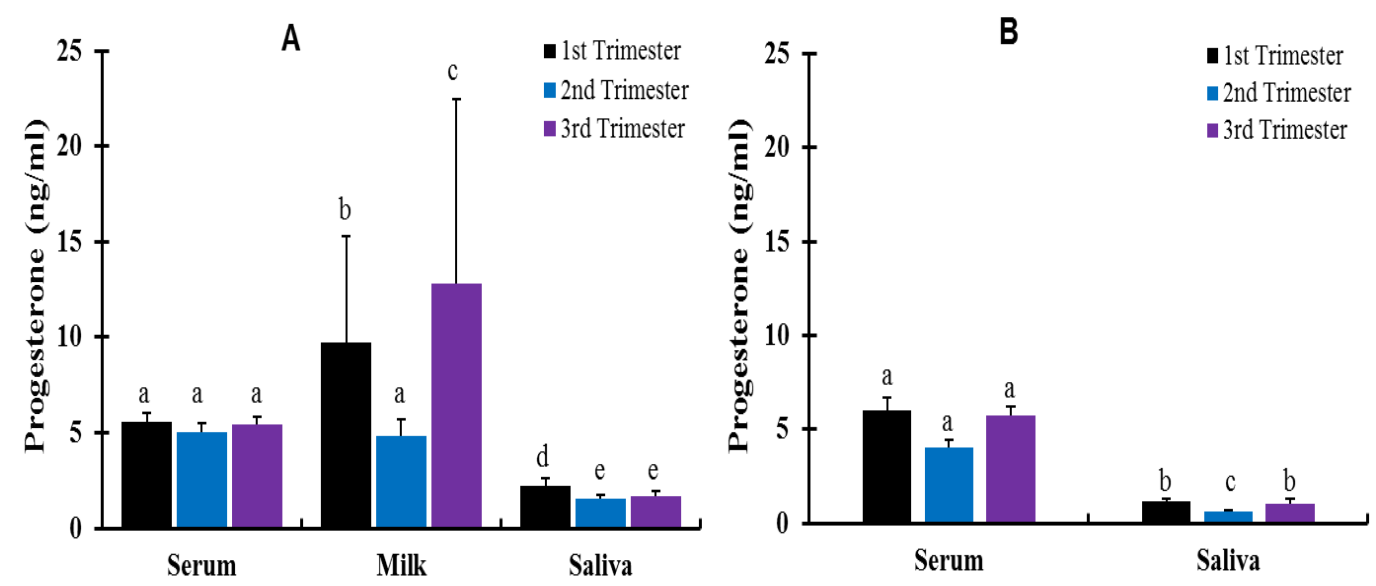

Figure 5. Effect of pregnancy stages on $\mathrm{P} 4$ concentration (Mean $\pm \mathrm{SEM}, \mathrm{ng} / \mathrm{ml})$ in crossbred cows $(\mathrm{A})$ and heifers $(\mathrm{B})$. Pregnant cows, $\mathrm{n}=114: 41,36 \& 37$ in $1^{\text {st }}, 2^{\text {nd }}$ and $3^{\text {rd }}$ trimesters, respectively; pregnant heifers, $n=43: 12,19 \& 12$ in $1^{\text {st }}, 2^{\text {nd }}$ and $3^{\text {rd }}$ trimesters respectively. Bars with different letters are significantly different, $p<0.05$; two-way ANOVA.

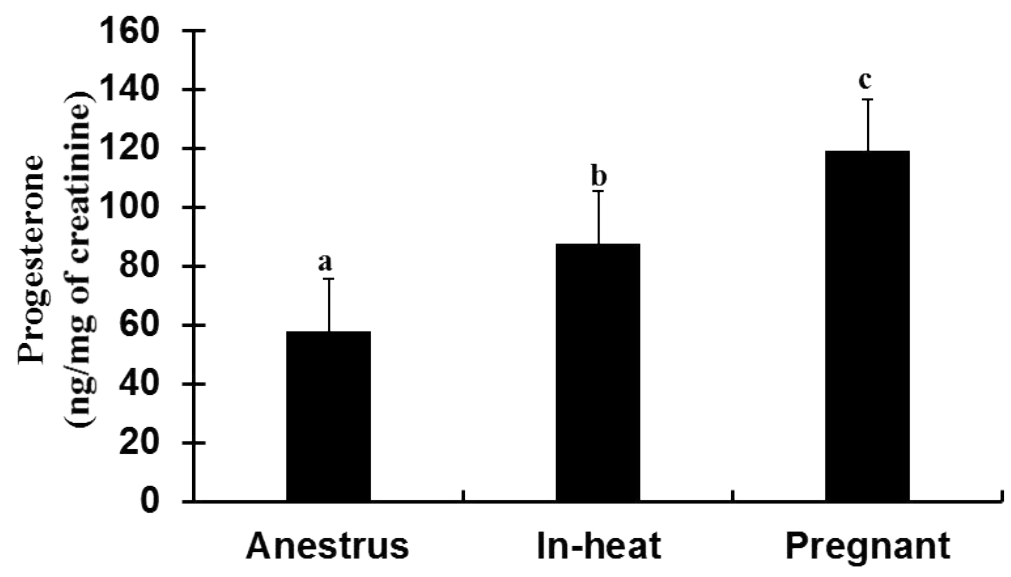

Figure 6. Urine $\mathrm{P} 4$ profile (Mean $\pm \mathrm{SEM}, \mathrm{ng} / \mathrm{mg}$ of creatinine) in crossbred dairy cows at different reproductive conditions; samples were collected from cows in and around Mekelle, Ethiopia. $\mathrm{N}=30$ : 8 anestrus, 4 in-heat and 18 pregnant. Bars with different letters are significantly different $(\mathrm{p}<0.05)$; One-way ANOVA.

A

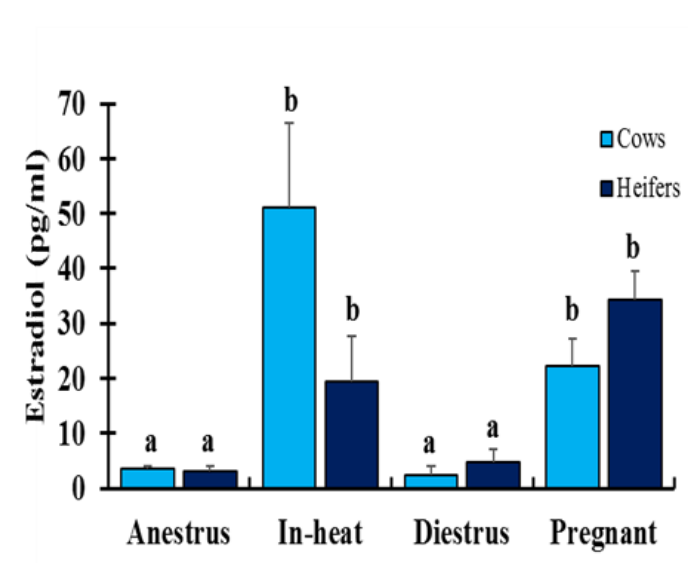

B

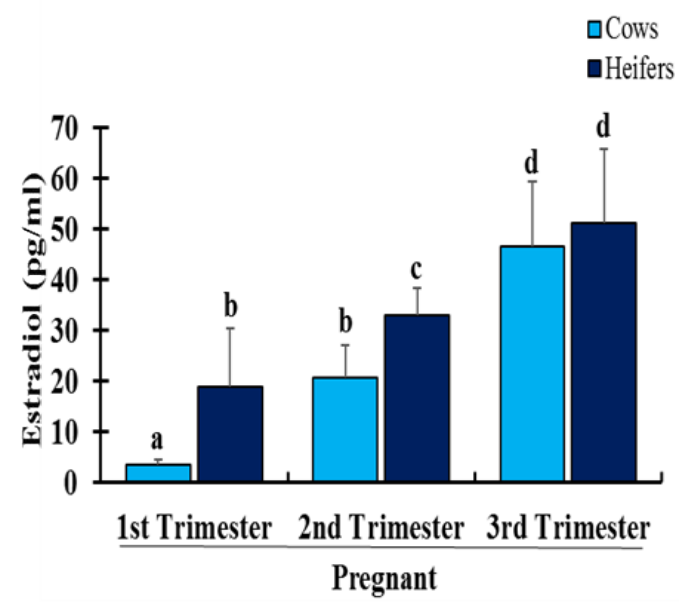

Figure 7. Diagrammatic representation of the mean serum estradiol concentration (Mean $\pm \mathrm{SEM}, \mathrm{pg} / \mathrm{ml}$ ) at different reproductive states (A) and based on stages of pregnancy (B) in crossbred dairy cows and heifers. $\mathrm{N}=172: 100$ cows; 24 anestrus, 5 in-heat, 14 diestrus, 54 pregnant ( 21 first, 16 second and 17 third trimester); 77 heifers; 19 anestrus, 5 in-heat, 14 diestrus, 39 pregnant ( 8 first, 22 second and 9 third trimester). Of 5 cows in-heat, 2 were included following induction of estrus using combination of CIDR-PGF2 $\alpha$-eCG (Chapter 6 ). In each graph, bars with different letters are significantly different $(\mathrm{p}<0.05)$; two-way ANOVA. 
The P4 level is measured, in the present study, in cycling cattle in diestrus. However, as the specific date of the previous ovulation or estrus was not available, P4 level of cattle at unknown stage of the estrous cycle, but with the existence of a palpable CL per-rectal palpation was measured. Some animals had high P4 levels $(\geq 1 \mathrm{ng} /$ $\mathrm{ml}$ ) in either of the samples collected twice at 11-day intervals with no breeding history postpartum, reflecting the animals were normally cycling. Hence, of the two samples tested per animals, the one with the higher P4 concentration was taken for analysis in diestrus cattle, assuming it is comparatively closer to the level when the animal is in the middle of her estrous cycle. Some cycling cattle had high P4 levels in both samples collected at 11-day interval. The reason for cows/ heifers having high $\mathrm{P} 4$ levels for an extended period could be due to a prolonged luteal phase [72]. A prolonged luteal phase is one of the common reproductive problems of dairy cows, occurring mostly from calving to 90 days postpartum $[73,74]$.

Ovarian cyclicity was determined based on the fluctuation of P4 levels in two samples collected 11 days apart with at least one of the samples having a $\mathrm{P} 4$ concentration $\geq 1 \mathrm{ng} / \mathrm{ml}$. That indicates the presence of a CL. The level of P4 in non-cycling (anestrous) cattle is low due to the absence of CL. In the present study, crossbred cattle that did not have CL during per-rectal palpation and was confirmed by quantitative laboratory ELISA to have serum and milk P4 levels $<1$ $\mathrm{ng} / \mathrm{ml}$, in two samples collected at 11-day intervals, were considered as true anestrus. This correlates with the commonly accepted threshold of $1.0 \mathrm{ng} / \mathrm{ml}$ for ovarian function [75]. However, several other studies used different P4 thresholds to distinguish luteal activity. A threshold of 0.5 $\mathrm{ng} / \mathrm{ml}$ was used to determine non-luteal cows [12], while a threshold of $3 \mathrm{ng} / \mathrm{ml}$ was used to indicate luteal activity in the analysis of milk P4 profiles [73]. The circulating P4 profile of crossbred cattle during luteal phase (diestrus) in the present study was similar to previous reports in HF cows in Thailand that used a serum RIA [55]. Conversely, serum P4 levels in diestrus cattle in the present study was higher than a previous report in crossbred cows in India [54]. In contrast, lower milk and serum $\mathrm{P} 4$ was recorded in diestrus cattle in the present study than reports in HF cows in the Netherlands [19] and Punganur cows in India [56]. Higher serum P4 levels recorded in the present study in diestrus heifers than in diestrus cows was in agreement with a previous report after administration of CIDR [76]. The P4 concentration in diestrus cattle in this study was higher than previous reports in Friesian /Jersey cattle $[15,16]$.

\section{P4 determination in pregnant cattle}

Progesterone is an essential hormone for the maintenance of pregnancy, however, the minimum concentrations of $\mathrm{P} 4$ required is not clearly understood [77]. The P4 concentration recorded in the present study in crossbred cattle in early stage (first trimester) of pregnancy was similar to previous reports in crossbred cattle as well as local breed (Zebu) cattle in other part of Ethiopia [78] and in Zebu cows in Bangladesh [58]. In contrast, crossbred cows and heifers in the present study had higher serum P4 during their early pregnancy than HF cows in Pakistan [10].

Milk P4 recorded in crossbred cattle in early pregnancy in the present study was similar to previous reports in Zebu cows in Bangladesh [58]. Conversely, comparatively lower milk P4 was recorded during early pregnancy in the present study than in previous reports [79]. P4 is soluble in milk fat, which is the reason for its higher level in milk than in blood [80]. The mean saliva P4 concentration detected in pregnant crossbred cows in this study was $>1 \mathrm{ng} / \mathrm{ml}$, which was higher than in previous reports $[15,16]$. In sheep, a mean P4 concentration of $1.8 \mathrm{ng} / \mathrm{ml}$ has been reported [81], which is similar to the value in pregnant cows in this study. The P4 level in saliva during first trimester of pregnancy was not significantly higher than second and significantly higher than third trimester and this was significantly higher in cows than in heifers. The higher P4 in cow saliva than in heifers may be because cows have comparatively well-developed reproductive physiology associated with previous calving and have larger ovaries with large CL. Previous reports have shown a positive correlation between the size of CL and P4 level [82].

Low milk P4 $(<1 \mathrm{ng} / \mathrm{mL})$ detected in pregnant cows in this study is in agreement with previous reports from British Colombia whereby 135 (29\%) cows in early pregnancy (50-60 days post-service) showed low milk P4 level [61]. Furthermore, Bulman and Lamming [83] reported that a pregnant cow calved successfully despite its milk P4 level between 8 and 16 days after insemination being basal.

Several previous studies have shown application of analysis of urinary steroid metabolites to determine pregnancy status in various species $[36,49,84,85]$, including human [86]. Both bovine blood and bovine CL tissue can convert P4 to 20ß-hydroxypregn-4-en-3one [87] that can be determined in urine. It has been reported that $5 \beta$-pregnane-3a,20 $\alpha$-diol detected in the urine of late pregnant cows [88]. Determination of the level of pregnanediol, which is an inactive metabolite of P4, has also been used as an indirect way of measuring P4 to diagnose pregnancy [49]. The higher P4 level detected in the urine of pregnant cows than in anestrus or cows in estrus, in the present study, reflects the formation and persistence of matured CL. The P4 profile in urine in this study was lower than a previous report in North American Bison cows [71], which may be due to breed difference.

Collecting blood samples for serum/plasma steroid hormone measurement requires venipuncture; hence, it is stressful and painful to the subject $[18,49]$. Furthermore, the challenges and the risk (to experts) collecting blood samples are formidable, particularly when working in farms where proper restraining facilities are not available. Unfortunately, almost all of the farms where the present study was conducted had no cattle crush for restraining the animals. Therefore, determining $\mathrm{P} 4$ or estradiol from serum samples for regular follow up of reproductive status of cattle is not safe for both the animals and the experts, particularly when someone approaches aggressive cattle. Though this particular study directly helped farmers involved in the study, as it was conducted at the field level, there were some farmers reluctant to provide the second blood samples, even some refrained from being included in the study. When asked why, they did not want their animals to feel pain and stressed, particularly those they thought were pregnant.

Milk is routinely used for determining reproductive status in lactating dairy cattle $[12,19]$. Our studies support previous work [89] that shows P4 concentrations in milk closely correlate those in the blood/plasma during the reproductive cycle in cows. Unlike the present findings that agreed with a recent report [48], previous reports demonstrated a positive correlation in the concentration of $\mathrm{P} 4$ in blood and saliva $[15,16]$. However, it has been proposed that the most significant problem with milk $\mathrm{P} 4$ measurements is the presence of considerable amount of lipids, which interfere with the assay $[90,91]$. Sampling has also been proposed to affect $\mathrm{P} 4$ concentration in milk [90]. Additionally, it has been reported that storage conditions can affect P4 level in bovine milk whereby frozen samples were reported to have higher P4 concentration compared to fresh samples [13]. Furthermore, the availability of milk is limited to lactating cattle only. 
Saliva and urine could be used as alternative samples to accurately determine the reproductive status of dairy cattle. Both saliva and urine can be collected through noninvasive methods, also from dry cows and heifers, hence avoid the animal welfare inconveniences when blood is collected or other inconveniences from using milk samples. Saliva has additional advantages due to its ease of storage, as it can be stored at $-20^{\circ} \mathrm{C}$ for over 6 months, at $48^{\circ} \mathrm{C}$ for 7 days, or at room temperature for $48 \mathrm{hr}$ with no significant change in steroid levels [92]. Furthermore, urine has several advantages over saliva, serum and milk: it can be collected in large volume that enables for multiple assays [93,94,95] and provides integrated hormone measures without the confounding effects of pulsatile secretion [37]. Additionally, the availability of steroid metabolite in higher concentration in urine (by two-to four-fold or more) than that of parent sex steroids in blood give greater advantage to the use of urine in domestic and wild animals $[49,85]$ or in women [96]. Although the P4 level in urine in the present study did not correlate with its level in matched serum, based on previous reports that have shown urine P4 profiles correlated with serum profiles [49,85], it might be more reliable specimen to use for monitoring reproductive status of dairy cattle. Furthermore, in the present study, collecting saliva was equally challenging as collecting blood in most cattle; whereas, urine was easily collected from both cows and heifers by the farmers themselves. This gives better advantage towards the use of urine in the future when simple and rapid on-farm Dipstick method is developed, and can be used by farmers themselves.

\section{Determination of serum estradiol}

Estradiol profiles recorded in crossbred heifers in estrus, in the present study, were in agreement with previous reports in Sahiwal heifers in estrus following treatment with CIDR in India [63], in Swedish dairy heifers [97] and in HF heifers following administration of PGF2 $\alpha$ in USA [98]. In contrast, the estradiol level recorded in heifers in estrus in the present study was comparatively higher than reports in crossbred beef heifers in USA [99]. Conversely, crossbred heifers that were in estrus in the present study had lower serum concentration of estradiol than previous reports in HF heifers in estrus induced by PGF2 $\alpha$ in USA [98] and in Bali heifers in Indonesia [100]. The reason for lower estradiol profiles in the present finding than in previous reports may be due to breed difference. The estradiol level in crossbred dairy cows in estrus, in the present study, was similar with previous reports in crossbred normally cycling or repeat-breeding cows in India that were in estrus [65] and in Sahiwal cows in India that were in estrus induced by CIDR administration [63]. In contrast, the present study recorded higher circulating estradiol in cows during estrus than previous reports in Punganur cows in India [56]. Conversely, the estradiol profile in cows in estrus in the present study was lower than a previous report in Bunaji cattle in Nigeria [101]. Higher estradiol levels were detected, in the present study, in cattle exhibiting estrus compared to anestrous or cycling (diestrus phase) cattle, which agrees with a previous report [102] that that showed a positive correlation between follicle size and peak estradiol concentration, and greater peak estradiol concentration in cows exhibiting estrus compared to not exhibiting estrus.

Serum concentration of estradiol in anestrous cattle or cycling cattle in the diestrus phase of the estrous cycle, in the present study, was in agreement with a previous report in postpartum crossbred beef cows with calves weaned $>30$ days and reported to have ovulatorysized follicles $(>10 \mathrm{~mm})$ but failed to exhibit standing estrus following Co-Synch protocol [102]. Conversely, the estradiol profile in serum in crossbred cattle in our study was lower than previous reports in postpartum (20-40 days) crossbred Angus beef cows with calves allowed to suckle without restriction throughout the experiment in USA [102], in Punganur cows in diestrus (in $12^{\text {th }}$ day of the estrous cycle) [56] and in anestrous or cycling (diestrus) Bunaji cattle in Nigeria [101]. The higher estradiol level in pregnant heifers than in heifers in estrus or other reproductive conditions (anestrus or diestrus) was in agreement with a previous report in Bunaji cattle in Nigeria [101]. However, the overall estradiol profile in serum in pregnant cattle in the present study was lower than a previous report [101]. The reason behind this could be breed difference.

A quantitative ELISA technique can be applied in the Ethiopian research laboratories and veterinary clinics to identify pregnant dairy cattle and assess ovarian function. However, unlike the on-farm ELISA, application of quantitative ELISA at field (farm) level is not possible due to its high cost and the requirement for skilled farm personnel $[25,103]$.

In conclusion, the present study confirmed that a quantitative ELISA technique could be used to accurately determine the steroid profile and monitor the reproductive status of dairy cattle. This enables the detection of cycling animals and hence to successfully breed them, and perform pregnancy diagnosis as early as 18-days post service. Lastly, the measurement of sex steroids in various sample types should provide a basis for further related studies in crossbred, as well as local breed cattle in the tropics and other regions.

\section{Conflicts of interest}

\section{The authors declare no conflict of interests.}

\section{Acknowledgment}

The authors would like to thank MRC Centre for Reproductive Health, College of Medicine and Veterinary Medicine, University of Edinburgh, for supporting A. B. Mekonnin and funding the study. Special thanks would be offered to Mekelle University, College of Veterinary Medicine, where our research team was based during the study and for the offer of transportation facilities and other supports. Authors would like to thank Tigray Regional State Agriculture Bureau for facilitating support team. Finally, deepest gratitude would be offered to farmers, AI Technicians, veterinarians, farm managers and attendants for their willingness and cooperation to conduct the study.

\section{References}

1. Barr HL (1975) Influence of estrus detection on days open in dairy herds. $J$ Dairy Sci 58: 246-247. [Crossref]

2. Britt JH (1985) Enhanced reproduction and its economic implications. J Dairy Sci 68 1585-1592. [Crossref]

3. Rao TKS, Kumar N, Kumar P, Chaurasia S, Patel NB (2013) Heat detection techniques in cattle and buffalo. Vet World 6: 363-369.

4. McDonald LE, Nichols RE, McNutt SH (1952) Studies on corpus luteum ablation and progesterone replacement therapy during pregnancy in the cow. Am J Vet Res 13: 446451. [Crossref]

5. Rekawiecki R, Kowalik MK, Slonina D, Kotwica J (2008) Regulation of progesterone synthesis and action in bovine corpus luteum. J Physiol Pharmacol 59 Suppl 9: 75-89. [Crossref]

6. Garrett JE, Geisert RD, Zavy MT, Morgan GL (1988) Evidence for maternal regulation of early conceptus growth and development in beef cattle. J Reprod Fertil 84: 437-446. [Crossref]

7. Mann GE, Mann SJ, Lamming GE (1996) The interrelationship between the maternal hormone environment and the embryo during the early stages of pregnancy. $J$ Reprod Fertil 21: 37 .

8. Forde N, Beltman ME, Lonergan P, Diskin M, Roche JF, et al. (2011) Oestrous cycles in Bos taurus cattle. Anim Reprod Sci 124: 163-169. [Crossref] 
9. Ashwood A (2012) Reproduction - oestrus \& puberty. Brahman News 174:1. Available in: http://www.brahman.com.au/technical information/reproduction/oestrusPuberty. html. (Accessed 05 August 2015).

10. Muhammd F, Sarwar A, Hayat CS, Anwar MI (2000) Peripheral plasma progesterone concentration during early pregnancy in Holstein Friesian cows. Pak Vet J 20: 166-168.

11. Lobago F, Bekana M, Gustafsson H, Kindahl H (2007) Longitudinal observation on reproductive and lactation performances of smallholder crossbred dairy cattle in Fitche, Oromia region, central Ethiopia. Trop Anim Health Prod 39: 395-403. [Crossref]

12. Romagnolo D, Nebel RL (1993) The accuracy of enzyme-linked immunosorbent assay and latex agglutination progesterone test for the validation of estrus and early pregnancy diagnosis in dairy cattle. Theriogenology 39: 1121-1128. [Crossref]

13. Domènech A, Pich S, Arís A, Plasencia C, Bach A, et al. (2011) Heat identification by $17 ß$-estradiol and progesterone quantification in individual raw milk samples by enzyme immunoassay. Electron J Biotechn 14: 1-5.

14. Bajema DH, Hoffman MP, Aitchison TE, Ford SP (1994) Use of cow-side progesterone tests to improve reproductive performance of high-producing dairy cows. Theriogenology 42: 765-771. [Crossref]

15. Kanchev LN, Marinova CHP, Stankov BM (1988) Bovine salivary progesterone applications to the assessment of ovarian function and early pregnancy diagnosis. Anim Reprod Sci 17: 1-8.

16. Gao Y, Short RV, Fletchure TP (1988) Progesterone concentrations in plasma, saliva and milk of cows in different reproductive status. Br Vet J 144: 262-268.

17. Swanand S (2012) Evaluation of salivary progesterone profiles as an indicator of reproductive status in equines. MSc dissertation. The University of Illinois at UrbanaChampaign, USA, 1-73.

18. Wong YF, Mao K, Panesar NS, Loong E-PL, Chang A-MZ, et al. (1990) Salivary estradiol and progesterone during the normal ovulatory menstrual cycle in Chinese women. Eur J Obstet Gynecol Reprod Boil 34: 129-135.

19. Roelofs JB, Van Eerdenburg FJ, Hazeleger W, Soede NM, Kemp B (2006) Relationship between progesterone concentrations in milk and blood and time of ovulation in dairy cattle. Short communication. Anim Reprod Sci 91: 337-343. [Crossref]

20. Ozturk S, Demir R (2010) Particular functions of estrogen and progesterone in establishment of uterine receptivity and embryo implantation. Histol Histopathol 25: 1215-1228. [Crossref]

21. Miller BG, Moore NW (1976) Effects of progesterone and oestradiol on endometria metabolism and embryo survival in the ovariectomized ewe. Theriogenology 6: 636 . [Crossref]

22. Allrich RD (1994) Endocrine and neural control of estrus in dairy cows. J Dairy Sci 77: 2738-2744. [Crossref]

23. Miller BG, Moore NW, Murphy L, Stone GM (1977) Early pregnancy in the ewe: effects of oestradiol and progesterone on uterine metabolism and on embryo survival. Aust J Biol Sci 30: 279-288. [Crossref]

24. Richards JS, Ireland JJ, Rao MC, Bernath GA, Midgley Jr AR, et al. (1976) Ovarian follicular development in the rat: hormone receptor regulation by estradiol, follicle stimulating hormone and luteinizing hormone. Endocrinology 99: 1562-1570. [Crossref]

25. Zhuang LZ, Adashi EY, Hsuch AJ (1982) Direct enhancement of gonadotropinstimulated ovarian estrogen biosynthesis by estrogen and clomiphene citrate. Endocrinology 110: 2219-2221. [Crossref]

26. Mekonnin AB, Harlow C, Howie F, Gidey G, Tadesse D, et al. (2015) Assessment of major reproductive problems and reproductive status of crossbred (Holstein Friesian X Zebu) dairy cattle in and around Mekelle, Tigray, Ethiopia. In abstracts of annual conference of the Society for Reproduction and Fertility, Oxford, UK. Oxford: SRF.

27. Nebel RL (1988) On-farm milk progesterone tests. J Dairy Sci 71: 1682-1690. [Crossref]

28. Cupps PT (1991) Reproduction in domestic animals. 4th edn, Elsevier. pp. 101.

29. Stanczyk FZ (2003) All progestins are not created equal. Steroids 68: 879-890. [Crossref]

30. Falcone T, Hurd WW (2007) Clinical reproductive medicine and surgery. Elsevier Health Sciences. pp. 22.

31. KLYNE W, WRIGHT AA (1959) Steroids and other lipids of pregnant cow's urine. $J$ Endocrinol 18: 32-45. [Crossref]

32. Denari JH, Farinati Z, Casas PR, Oliva A (1981) Determination of ovarian function using first morning urine steroid assays. Obstet Gynecol 58:5-9. [Crossref]
33. Baulieu E-E, Kelly PA (1990) Hormones: From Molecules to Disease. Springer Science \& Business Media. pp. 401.

34. O'Malley BW, Strott CA (1999) Steroid hormones: metabolism and mechanism of action. In: Yen SSC, Jaffe RB, Barbieri RL. Eds. Reproductive endocrinology: physiology, pathophysiology and clinical management. Philadelphia, USA: WB Saunders. pp. 110-133.

35. Josimovich J (2013) Gynecologic endocrinology. Springer Science \& Business Media pp. $9-29$

36. Volkery J, Gottschalk J, Sobiraj A, Wittek T, Einspanier A (2012) Progesterone, pregnanediol-3-glucuronide, relaxin and oestrone sulphate concentrations in saliva, milk and urine of female alpacas (Vicugna pacos) and their application in pregnancy diagnosis. Vet Rec 171: 195. [Crossref]

37. Munro CJ, Stabenfeldt GH, Cragun JR, Addiego LA, Overstreet JW, et al. (1991) Relationship of serum estradiol and progesterone concentrations to the excretion profiles of their major urinary metabolites as measured by enzyme immunoassay and radioimmunoassay. Clin Chem 37: 838-844. [Crossref]

38. Robertson HA, Sarda IR (1971) A very early pregnancy test for mammals: it application to the cow, ewe and sow. J Endocrinol 49: 407-419. [Crossref]

39. Robertson HA (1972) Sequential changes in plasma progesterone in the cow during the estrous cycle, pregnancy, at parturition and post-partum. Can J Anim Sci 52: 645-658.

40. Shemesh M, Ayalon N, Lindner HR (1973) Early pregnancy diagnosis based upon plasma progesterone levels in the cow and ewe. J Anita Sci 36: 726-729.

41. Tallon DF, Gosling JP, Buckley PM, Dooley MM, Cleere WF, et al. (1984) Direct solid-phase enzyme immunoassay of progesterone in saliva. Clin Chem 30: 1507-1511. [Crossref]

42. Kanchev LN (1976) Determination of the binding percentage of 17ß-oestradiol, progesterone and testosterone to plasma proteins in cattle. In: Proceedings of the 8th Congress on Animal Reproduction and A.I., Krakow, Poland. 3: 141-143.

43. Riad-Fahmy D, Read GF, Walker RF, Griffiths K (1982) Steroids in saliva for assessing endocrine function. Endocr Rev 3: 367-395. [Crossref]

44. McGarrigle HHG, Lachelin GCL (1984) Increasing saliva (free) oestradiol to progesterone ratio in late pregnancy: a role for oestriol in initiating spontaneous labour in man? Br Med J 289: 457-459. [Crossref]

45. Sorgo W, Manella B, Zachmann M (1983) Radioimmunoassay of progesterone in saliva. Horm Res 17: 153-159. [Crossref]

46. Vining RF, McGinley RA (1982) Transport of steroids from blood to saliva. In: Read, G. F., Riad-Fahmy, D., Walker, R. F. and Griffiths, K. (Editors) (Editors) Immunoassays of Steroids in Saliva. Cardiff, UK: Alpha Omega. pp 56-63.

47. Qureshi ZI, Lodhi L, Bajwa MA, Muhamma G, Ahmad I (1999) Estradiol-17ß concentration in different biological fluids during the oestrous cycle in buffalo. Pak J Agri Sci 36 .

48. Sathe SR (2012) Evaluation of salivary progesterone profiles as an indicator of reproductive status in equines. MSc Dissertation, University of Illinois at UrbanaChampaign, Illinois, USA.

49. Yang CJ, Wu LS, Liu SH, Lin JH (2004) Monitoring the reproductive status of dairy cows by urinary pregnanediol glucuronide. Asian-Aust J Anim Sci 17: 460-466.

50. Chen HL, Chen YL, Wu LS, Kaphle K, Lin JH (2006) Establishment and application of enzyme immunoassay for saliva cortisol in Taiwanese context. $J$ Immunoassay Immunochem 27: 239-249. [Crossref]

51. Hailu B, Gebrekidan B, Raju S, Birhanu A, Tadesse G (2015) Effects of gonadotropinreleasing hormone analogue in enhancements of pregnancy in repeat breeding dairy cows in and around Mekelle, Tigray, Ethiopia. Anim Vet Sci 3: 12-17.

52. DEFRA (2001) Condition scoring of dairy cows. Action on animal health and welfare The Department for Environment, Food \& Rural Affairs.

53. Bömer U, Szász G, Bablok W, Busch EW (1979) A specific fully enzymatic method for creatinine: reference values in serum. J Clin Chem Clin Biochem 17: 679-882. [Crossref]

54. Balakrishnan GP, Chinnaiya GP, Nair PG, Jagannadha RA (1986) Studies on serum progesterone levels in Zebu $\times$ Holstein heifers during pre- and peripubertal periods. Anim Reprod Sci 2: 11-15.

55. Vadhanakul N, Chankrachang A, Suthikrai W, Hongyuntarachai K (2008) Progesterone profiles and conception of dairy cattle administered with gonadotropin releasing hormone in luteal phase post insemination. J Mahanakorn Vet Med 3: 46-55.

56. Naik BR, Siva-Kumar AV, Bramhaiah KV, Ravi A, Chakravarthi VP (2013) Estrogen and Progesterone hormone levels in Punganur Cattle. IOSR-JAVS 2: 50-53. 
57. Suthanthirakannan R, Rameshkumar K (2014) Quantitative analysis of biochemicals and hormones in bovine saliva (Bos indicus) with reference to estrus detection. The Scitech J 1: 26-29.

58. Alam MGS, Ghosh A (1994) Plasma and milk progesterone concentrations and early pregnancy in Zebu cows. AJAS 7:131-136

59. Pope GS, Majzlik I, Ball PJ, Leaver JD (1976) Use of progesterone concentrations in plasma and milk in the diagnosis of pregnancy in domestic cattle. Br Vet J 132: 497 506. [Crossref]

60. Moore AS, Spahr SL (1991) Activity monitoring and an enzyme immunoassay for milk progesterone to aid in the detection of estrus. J Dairy Sci 74: 3857-3862. [Crossref]

61. Rajamahendran R, Burton B, Shelford J (1993) A field study on the usefulness of milk progesterone determination to confirm estrus and pregnancy of dairy cows in the Fraser Valley area of British Columbia. Can Vet J 34: 349-352. [Crossref]

62. Nebel RL, Whittier WD, Cassell BG, Britt JH (1987) Comparison of on-farm laboratory milk progesterone assays for identifying errors in detection of estrus and diagnosis of pregnancy. J Dairy Sci 70: 1471-1476. [Crossref]

63. Singh H, Luthra RA, Khar SK, Nanda T (2006) Oestrus Induction, Plasma Steroid Hormone Profiles and Fertility Response after CIDR and eCG Treatment in Acyclic Sahiwal Cows. Asian-Aust J Anim Sci 19: 1566-1573.

64. Ambrose DJ, Colazo MG (2007) Reproductive Status of Dairy Herds in Alberta: A Closer Look. WCDS Advances in Dairy Technology 19: 227-244.

65. Barui A, Batabyal S, Ghosh S, Saha D, Chattopadhyay S (2015) Plasma mineral profiles and hormonal activities of normal cycling and repeat breeding crossbred cows: A comparative study. Vet World 8: 42-45. [Crossref]

66. Kafi M, Zibaei M, Rahbari A (2007) Accuracy of oestrus detection in cows and its economic impact on Shiraz dairy farms. IJVR 8:131-137.

67. Scommegna A, Chattoraj SC (1967) Urinary pregnanediol and creatinine excretion in the female of menstrual age. Obstet Gynecol 30: 242-248. [Crossref]

68. Jones PH, Erb RE (1968) Levels of 5 ß-pregnan-3a,6a-diol-20-one in urine and its relationship to other metabolites of progesterone in urine of the nonpregnant domestic sow. J Anita Sci 27:1054

69. Albin RC, Clanton DC (1966) Factors contributing to the variation in urinary creatinine and creatinine-nitrogen ratios in beef cattle. J Anim Sci 25: 107-112. [Crossref]

70. Hodgen GD, Erb RE, Plotka ED (1967) Estimating creatinine excretion in sheep. $J$ Anim Sci 26: 586-589. [Crossref]

71. Kirkpatrick JF, Kincy V, Bancroft K, Shideler SE, Lasley BL (1991) Oestrus cycle of the North American bison (Bison bison) characterized by urinary pregnanediol-3glucuronide. J Reprod Fertil 93: 541-547. [Crossref]

72. Ranasinghe RM, Nakao T, Yamada K, Koike K, Hayashi A, et al. (2011) Characteristics of prolonged luteal phase identified by milk progesterone concentrations and its effects on reproductive performance in Holstein cows. J Dairy Sci 94: 116-127. [Crossref]

73. Lamming GE, Darwash AO (1998) The use of milk progesterone profiles to characterise components of subfertility in milked dairy cows. Anim Reprod Sci 52: 175-190. [Crossref]

74. Shrestha HK, Nakao T, Higaki T, Suzuki T, Akita M (2004) Resumption of postpartum ovarian cyclicity in high producing Holstein cows. Theriogenology 61: 637-649. [Crossref]

75. Delwiche MJ, Tang X, BonDurant RH, Munro CJ (2001) Estrus detection with a progesterone biosensor. Trans ASAE 44: 2003-2008.

76. Nascimento AB, Souza AH, Guenther JN, Costa FP, Sartori R, et al. (2013) Effects of treatment with human chorionic gonadotrophin or intravaginal progesterone-releasing device after AI on circulating progesterone concentrations in lactating dairy cows. Reprod Fertil Dev 25: 818-824. [Crossref]

77. Lucy MC (2001) Reproductive loss in high-producing dairy cattle: where will it end? $J$ Dairy Sci 84: 1277-1293. [Crossref]

78. Lobago F, Bekana M, Gustafsson H, Beckers JF, Yohannes G, et al. (2009) Serum profiles of pregnancy-associated glycoprotein, oestrone sulphate and progesterone during gestation and some factors influencing the profiles in Ethiopian Borana and crossbred cattle. Reprod Domest Anim 44: 685-692. [Crossref]

79. Aly KAREN, Árpád Csaba BAJCSY, Rosa MINOIA, Rezső KOVÁCS, Noelita Melo DE SOUSA, et al. (2014) Relationship of progesterone, bovine pregnancy-associated glycoprotein-1 and nitric oxide with late embryonic and early fetal mortalities in dairy cows. J Reprod Develop 60:162-167. [Crossref]

80. Noakes DE, Parkinson TJ, England GCW (2009) Veterinary Reproduction \& Obstetrics. Ed by: Noakes DE, Parkinson TJ, England GCW. 9th Ed., London, UK: Saunders.
81. Needham C (2007) An investigation into the use of salivary progesterone to diagnose pregnancy in sheep. BSc dissertation. The University of Nottingham, UK.

82. Ali A, Fahmy S (2007) Ovarian dynamics and milk progesterone concentrations in cycling and non-cycling buffalo-cows (Bubalus bubalis) during Ovsynch program. Theriogenology 68: 23-28. [Crossref]

83. Bulman DC, Lamming GE (1978) Milk progesterone levels in relation to conception, repeat breeding and factors influencing acyclicity in dairy cows. J Reprod Firt 54 447-458. [Crossref]

84. Liskowski L, Wolf RC (1972) Urinary excretion of progesterone metabolites in pregnant rhesus monkeys. Proc Soc Exp Biol Med 139: 1123-1126. [Crossref]

85. Lasley BL, Kirkpatrick JF (1991) Monitoring ovarian function in captive and freeranging wildlife by means of urinary and fecal steroids. A review. $J$ Zoo Wildl Med 22:23-31.

86. Vaikkinen A, Rejšek J, Vrkoslav V, Kauppila TJ, Cvacka J, Kostiainen R (2015) Feasibility of desorption atmospheric pressure photoionization and desorption electrospray ionization mass spectrometry to monitor urinary steroid metabolites during pregnancy. Anal Chim Acta 880: 84-92. [Crossref]

87. SHORT RV (1958) Progesterone in blood. I. The chemical determination of progesterone in peripheral blood. $J$ Endocrinol 16: 415-425. [Crossref]

88. Heitzman RJ, Thomas GH (1965) Evaluation by gas chromatography of the urinary steroids of the pregnant dairy cow. $J$ Endocrinol 33: 455-467. [Crossref]

89. Laing JA, Heap RB (1971) The concentration of progesterone in the milk of cows during the reproductive cycle. Br Vet J 127: xix-xxii. [Crossref]

90. Hoffman B, Hamburger R (1973) Progesterone in der Milch: Radioimmuno-logische Bestimmung, Beziehungen zur Gelbkorper funktion and milch felt konzentration. Zuchthygiene 8:154.

91. Inaudi P, Bacigalupo M, Monittola C, Lugaro G, Genazzani AR (1982) Pregnancy diagnosis in cattle by a rapid and highly reliable method for progesterone determination in milk. J Reprod Fert 65:265-273. [Crossref]

92. Huang NH, Dill B, Besch PK, Hinkley CM (1981) Radioimmunoassay of unconjugated estriol in saliva. Clin Chem 27: 1080 .

93. Collins WP, Collins PO, Kilpatrick MJ, Manning PA, Pike JM, et al. (1979) The concentrations of urinary oestrone-3-glucuronide, $\mathrm{LH}$ and pregnanediol-3alpha-glucuronide as indices of ovarian function. Acta Endocrinol (Copenh) 90: 336-348. [Crossref]

94. Kesner JS, Wright DM, Schrader SM, Chin NW, Krieg EFJr (1992) Methods of monitoring menstrual function in field studies: efficacy of methods. Reprod Toxicol 6: 385-400.

95. Lasley BL, Mobed K, Gold EB (1994) The use of urinary hormonal assessments in human studies. Ann N Y Acad Sci 709: 299-311. [Crossref]

96. Shideler SE, DeVane GW, Kalra PS, Benirschke K, Lasley BL (1989) Ovarian-pituitary hormone interactions during the perimenopause. Maturitas 11: 331-339. [Crossref]

97. Båge R (2002) On repeat breeding in dairy heifers. With special focus on follicular dynamics, ovulations, and oocyte quality. Doctoral Thesis, Swedish University of Agricultural Science, Uppsala, Sweden.

98. Coe BL, Allrich RD (1989) Relationship between endogenous estradiol-17 beta and estrous behavior in heifers. J Anim Sci 67: 1546-1551. [Crossref]

99. Perry GA, Smith MF, Roberts AJ, MacNeil MD, Geary TW (2007) Relationship between size of the ovulatory follicle and pregnancy success in beef heifers. $J$ Anim Sci 85: 684-689. [Crossref]

100. Airin CM, Putro PP, Astuti P, Baliarti E (2014) Level of estradiol-17ß serum and ovarian follicular dynamics in short estrous cycle of Bali cattle. J Indonesian Trop Anim Agric 39: 23-29.

101. Opara MN, Okoli1 CI, Udo H, Adeyemo O (2006) Ovarian morphology and estradiol-17ß concentrations in serum and follicular fluid of slaughtered zebu cattle in Ibadan, Nigeria. Vet. Arhiv 76: 403-411.

102. Perry GA, Swanson OL, Larimore EL, Perry BL, Djira GD, et al. (2014) Relationship of follicle size and concentration of estradiol among cows exhibiting or not exhibiting estrus during a fixed-time AI protocol. Domestic Anim Endocrinol 48: 15-20. [Crossref]

103. Gordon IR (2005) Pregnancy testing technology In: Reproductive Technologies in Farm animals. USA: CABI Publishing.

Copyright: (C)2017 Mekonnin AB. This is an open-access article distributed under the terms of the Creative Commons Attribution License, which permits unrestricted use, distribution, and reproduction in any medium, provided the original author and source are credited. 